\title{
AN ECONOMIC ANALYSIS OF SOME FACTORS AFFECTING IN MARKETING EFFICIENCY OF DRY ONION CROP USING THE TOBIT REGRESSION MODEL
}

Q. T. Jassam

Lecture

\author{
A. T. Abd Al-majeed \\ Lecture
}

E. H. Ali

Assist. Prof.

Dept. Agri. Economics Coll. of Agri. Engine. Scie. - University of Baghdad

qais.t@coagri.uobaghdad.edu.iq amena.tariq@coagri.uobaghdad.edu.iq eskanderhali81@gmail.com

\begin{abstract}
The study was aimed to evaluate the marketing efficiency of dry Onion crop in Salah al-Deen, as estimate the impact of some quality and quantity factors in the efficiency of marketing process of crop using Tobit regression model. The average marketing efficiency of the research sample was $71.3686 \%$. The marketing margins differed according to the marketing channel followed in marketing the crop. The qualitative and quantitative variables in the model are productivity, family size, distance from the market, educational level. The estimated model revealed that a variable productivity is the most important and influential in marketing efficiency, followed by the variable of the distance between the farm and the market, then the variables of family size and educational level, with less influence according to the estimated model values. The Wald statistical test, which follows the chisquare distribution at degree of freedom d.f4, revealed the significant values of the traits of Tobit regression model as a whole $0.0017<0.05$, this means the independent variables included in the model have a statistically significant effect to predict the value of the qualitative dependent variable. The researchers according to the average value of marketing efficiency has concluded the possibility to raise the value of marketing efficiency by $\mathbf{2 9 . 3 6 \%}$ in the case of efficient use of resources in the marketing process, as well as the difference in the value of the influence of quantitative and qualitative independent factors on marketing efficiency according to the values of their traits, and the increasment in marketing margins according to the different marketing channels followed in marketing the crop. The research recommended the need to work on increase the marketing efficiency and reducing the high marketing margins received by intermediary agents, with need provide marketing services greater than these intermediaries.
\end{abstract}

Key words: marketing cost, qualitative factors, L.P.M model, marketing margins, marketing channels .

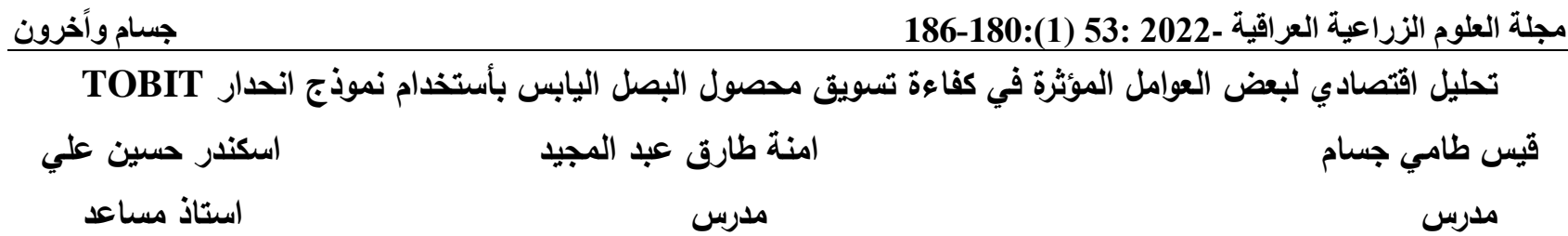

$$
\text { جامعة بغداد - كلية علوم الهندسة الزراعية - قسم الاقتصاد الزراعي ملري }
$$

هدف البحث الى قياس الكفاءة التسويقية لتسويق محصول البصل في محافظة صلاح الدين, وكذلك تقدير اثر بعض العوامل النوعية و الكمية في كفاءة العملية التسويقية للمحصول باستخدام نموذج انحدار Tobit , كان متوسط الكفاعة التسويقية لعينة البحث اختلفت حسب القناة التسويقية المتبعة في التسويق للمحصول, ان المتغيرات النوعية والكمية في النموذج هي, الانتاجية, حجم العائلة, البعد عن السوق, المستوى التعليمي, و نلاحظ من النموذج المقر ان متغير الانتاجية هو الاكثر تأثيرا في الكفاعة التسويقية يليه متغير المسافة بين المزئة فئية

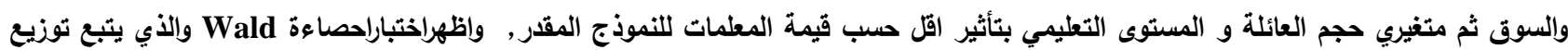
كاي عند درجة حرية d.f=4 معنوية معلمات نموذج انحدار تويت ككل 0.0017 > 0.05 وهذا يعني ان المتغيرات المستقلة الداخلة في النموذج ذات

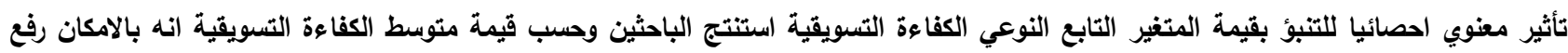
قيمة الكفاءة التسويقية وينسبة 29.36\% في حالة الاستخدام الكفوء للموارد في العملية التسويقية , وايضا اختلاف قيمة تأثير العوامل المستقلة الكمية والنوعية في الكفاعة التسويقية وحسب قيم معلماتها , وارتفاع الهوامش التسويقية باختلاف القتوات التسويقية المتبعة في تسويق المحصول, و و

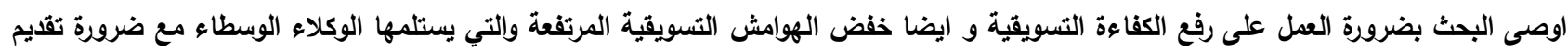
خدمات تسويقية اكبر من لان هولاء الوسطاء.

الكلمات المفتاحية: التكاليف التسويقية , العوامل النوعية, الهوامش التسويقية, نموذج الانحدار الاحتمالي ,القتوات التسويقية. 


\section{INTRODUCTION}

Onion is an important economic crop; it has a huge part of revenues and income of the producer, as well as for the consumer as it is a main source of nutrition, and medicinal uses (5). The study of marketing agricultural products for consumption is one of the important topics; the transportation of vegetable products from the producer to the consumer takes great importance for the researchers in the agricultural production fields and consumption, as it contributes in marketing decisions at the individual agricultural establishment level or marketing agencies (12). The agricultural products marketing is closely related to the production process to the point that some economists indicate that marketing should precede production, due to the need to know how to dispose of the agricultural commodity before making a production decision (14). The study of marketing efficiency and measuring marketing margins is one of the most important topics when conducting marketing studies, because it traces the various agricultural commodities within the marketing path from producer to consumer (4). The study of marketing efficiency is one of the most important traits used to measure the performance of marketing institutions or those in the marketing process (8). As indicated by the sources $(16,19)$. One of the main objectives of any research is to analyze the relationship between a group of variables in order to find a specific formula that describes this relationship between these variables (12). If the variables are quantitative, the relationship can be analyzed using regular regression models which is not appropriate for the independent, dependent, qualitative, or ordinal variables; while the qualitative response models are used to analyze and describe the relationship between the variables and among these qualitative models are the linear probability model L.P.M, Logit regression model and Probit regression model (3). As indicated by the sources $(24,25)$. This study was aimed to evaluate the marketing efficiency of dry Onion crop in Salah Al-Deen, as estimate the impact of some quality and quantity factors in the efficiency of marketing, for research problem is summarized by the decrease in marketing efficiency, which is affected by a group of factors, including quantitative, which are the familiar and can be measured, as well as qualitative factors that affect the value of marketing efficiency, which were not previously addressed; also the high marketing margins, which lead to a decrease in the received value and percentage by the agricultural producer. The research hypothesis is based on some qualitative factors that affect the reduction of the marketing efficiency of dry Onion crop, and the fluctuation of marketing margins according to the length of the channel or the marketing path. this research was aimed to evaluate the marketing efficiency of the dry onion crop, and estimate the effect of some qualitative factors on the efficiency of the marketing process of the crop. Data were obtained from primary, office, and field sources, using a questionnaire form prepared for this purpose that included a sample of 33 crop farmers, wholesalers, and retailers. The research importance rely on using an important analytical method that has not been previously included in marketing studies to interpret and measure the effect of qualitative factors on marketing efficiency; moreover, for the importance of dry Onion crop for consumer, and farmers as one of the main sources of farm income, the dry Onion production in Iraq for the year 2019 was about 15,426 tons, which accounted for $7.76 \%$ of the total production of tubers and bulbs at the country (17). the areas cultivated of Onion crop nationwide amounted to about 157.6 thousand hectare and formed $24.4 \%$ of the total areas cultivated with tubers and bulbs (11).

\section{MATERIALS AND METHODS}

The research was conducted according to the calculation of the amount of marketing efficiency; the efficiency of marketing services through the marketing paths is one of the factors affecting the stability of production and agricultural expansion; the marketing efficiency can be defined as the transfer of goods from producers to consumers at the lowest possible cost with the provision of services that are compatible with consumers desire and their paying ability, which means that the service quality should neither be low nor high in relation to the desired cost to 
consumers (23).Also, it is to maximize the ratio between marketing inputs and outputs $(2,1)$. There are some methods that can be used to define the efficiency of the marketing system; it is a group of applied indicators that help in evaluate the efficiency of the marketing system, including the partial comparison method, Shephard method, price spread, market composition, and mathematical equations; in this research, the method of mathematical equations was used, as the equations are used to estimate and calculate the marketing efficiency, and one of the following equations can be used to calculate the efficiency and these equations (4):

$1-\mathrm{ME}=100-(\mathrm{MC} / \mathrm{MC}+\mathrm{PC}) * 100$

$2-\mathrm{ME}=100-(\mathrm{MC}+\mathrm{PC} / \mathrm{VCMP}) * 100$

$3-\mathrm{ME}=100-(\mathrm{MM} / \mathrm{MM}+\mathrm{PC}) * 100 \quad$ (22).

$\mathrm{ME}=$ Marketing Efficiency, $\mathrm{MM}=$ Marketing Margins, $\mathrm{MC}=$ Marketing Costs $\mathrm{PC}=$ Production Costs, VCMP $=$ Value Cost of Marketed Products.

\section{RESULTS AND DISCUSSION}

After applying the equation 1; results in table 1 was revealed according to the calculated data.

Table1. The marketing efficiency of the research sample

\begin{tabular}{|c|c|c|c|c|c|c|c|}
\hline Farm & $\begin{array}{c}\text { Markwting } \\
\text { Efficiency } \\
\%\end{array}$ & $\begin{array}{c}\text { Marketing } \\
\text { Cost } \\
\text { I.D/Ton }\end{array}$ & $\begin{array}{c}\text { Product } \\
\text { Cost } \\
\text { I.D/Ton }\end{array}$ & Farm & $\begin{array}{l}\text { Markwting } \\
\text { \% Efficiency }\end{array}$ & $\begin{array}{l}\text { Marketing } \\
\text { Cost } \\
\text { I.D/Ton }\end{array}$ & $\begin{array}{c}\text { Product } \\
\text { Cost } \\
\text { I.D/Ton }\end{array}$ \\
\hline 1 & 64.48 & 65000 & 118000 & 18 & 73.72 & 56500 & 158500 \\
\hline 2 & 68.52 & 56500 & 123000 & 19 & 70.83 & 66500 & 161500 \\
\hline 3 & 71.09 & 61000 & 150000 & 20 & 69.38 & 69500 & 157500 \\
\hline 4 & 67.22 & 69000 & 141500 & 21 & 73.81 & 61000 & 172000 \\
\hline 5 & 69.83 & 63500 & 147000 & 22 & 72.25 & 64500 & 168000 \\
\hline 6 & 71.42 & 65000 & 162500 & 23 & 75.77 & 51000 & 159500 \\
\hline 7 & 72.94 & 57500 & 155000 & 24 & 73.11 & 60500 & 164500 \\
\hline 8 & 68.637 & 66500 & 145500 & 25 & 70.41 & 67000 & 159500 \\
\hline 9 & 74.04 & 54500 & 155500 & 26 & 74.05 & 58500 & 167000 \\
\hline 10 & 69.61 & 70500 & 161500 & 27 & 71.76 & 65500 & 166500 \\
\hline 11 & 75.55 & 55000 & 170000 & 28 & 72.17 & 61500 & 159500 \\
\hline 12 & 69.79 & 67500 & 156000 & 29 & 69.43 & 68000 & 154500 \\
\hline 13 & 73.46 & 58500 & 162000 & 30 & 73.11 & 62500 & 170000 \\
\hline 14 & 72.31 & 60500 & 158000 & 31 & 70.81 & 68000 & 165000 \\
\hline 15 & 72.72 & 58500 & 156000 & 32 & 70.88 & 61000 & 148500 \\
\hline 16 & 70.06 & 67500 & 158000 & 33 & 70.17 & 66500 & 156500 \\
\hline 17 & 71.67 & 65000 & 164500 & Average & 71.36 & 62712.12 & 156742.4 \\
\hline
\end{tabular}

Source: According to the questionnaire forms and Formula No.1

Previous researches and studies indicated that when the average marketing efficiency percent is more than $50 \%$, then the sample or the studied community has a marketing efficiency, which is in the markets where marketing services exist; in this research study sample, the average marketing efficiency ratio was about $71 \%$, despite of the lack of marketing services were provided except for packing, transportation storage, cleaning and drying operations of the crop, which the farmer performs. As for the marketing intermediaries, they are only perform the sales, purchase or storage operations, so the marketing efficiency calculated as the average is low in comparison to the type of operations and marketing services provided in the marketing path, which is attributed to the high marketing margins of the marketing stages within the marketing channel to increase marketing costs and intermediaries profits; the intermediaries profits are the large part of the consumer payments, and results in table 1 revealed the variety in the marketing efficiency percent for 
each agricultural product according to the difference in production costs and also the distance from the wholesale market, the crop transportation cost, the quality of the different methods, the packaging method, and the services applied in the farm for the marketed crop.

\section{Marketing Margins}

The marketing margins study is one of the most important criteria in order to identify the marketing differences and the affecting to recognize the marketing problems. Marketing margin is the difference between the retail price and the farm price, including the marketing costs and intermediaries profits; the calculation can be in an absolute or relative method, which expresses the absolute margins in monetary units $(21,15)$. The value of the marketing margin varies according to the channel or marketing approach (3). Results in Table 2 revealed the most important marketing channels for the onion crop and marketing margins (M.M) of each channel.

Table 2. The most important marketing channels and the marketing margins of each channel.

\begin{tabular}{|c|c|c|c|c|c|}
\hline Marketing channel & $\begin{array}{c}\underline{2} \\
\text { Average price } \\
\text { producer I.D/Kg }\end{array}$ & $\begin{array}{c}\underline{3} \\
\text { Average } \\
\text { price } \\
\text { wholesalers } \\
\text { I.D/Kg } \\
\end{array}$ & $\begin{array}{c}\underline{4} \\
\text { Average } \\
\text { price } \\
\text { consumer } \\
\text { I.D/Kg } \\
\end{array}$ & $\begin{array}{l}\stackrel{5}{\mathbf{5}} \\
\text { M.M. } \\
\text { Absolute } \\
\text { I.D/Kg }\end{array}$ & $\begin{array}{l}\frac{6}{\text { Farmer }} \\
\text { ratio } \%\end{array}$ \\
\hline Producer - consumer (direct) & 450 & - & 450 & $\mathbf{0}$ & $\% 100$ \\
\hline $\begin{array}{r}\text { Producer - wholesalers - retailers - } \\
\text { consumer }\end{array}$ & 320 & 450 & 600 & 280 & $\% 53.3$ \\
\hline Producer - wholesalers - consumer & 342 & 450 & 450 & 108 & $\% 76.1$ \\
\hline
\end{tabular}

Source: based on the questionnaire forms.

I.D = Iraqi Dinars

Column 5 = 4 - 2 (Consumer Price - Product Price),

Column $6=(4 / 2) * 100$ i.e. (farm price / consumer price) $* 100(13)$.

Results in Table 2 revealed that the marketing margin varies according to the marketing channel, the decrement in the marketing margin and the increasment in the percent of producer return is inversely with the marketing channel length; in the first channel, the absolute marketing margin was equal to zero, and the producer's return of the dinar was $100 \%$, while in the second marketing channel, the absolute marketing margin was 280 dinars. $\mathrm{kg}$, and the product's return of the dinars was $53.3 \%$, and the third marketing channel, the absolute marketing margin was 108 dinars. $\mathrm{kg}$, and the product's return of the dinar was $76.1 \%$. Despite the increase in the marketing margin in the presence of more intermediaries, this increasment in the marketing margin was not proportional with any increasment in marketing services.
Estimate the Tobit Model to Evaluate the Impact of Some Factors on Marketing Efficiency

The Tobit model is an extension of earlier models such as logit, probit and it can be used when the dependent variable contains zero and continuous views $(7,6)$. It is called (T.C.T.R) Tobit Censored Truncated Regression, and zero or negative observations can be replaced by zero (20).It is known as the finite or confined regression model and allows to deal with the distribution characteristics of competency levels $(18,9)$. In the research, the T.C.T.R method was used, as all observations were entered with the replacement of zero and negative views in the dependent variable or marketing efficiency with zero: by using Maximum Likelihood method and the Eviews statistical program, the Tobit model was estimated to evaluate the effect of variables, including family size, productivity, distance between farm and market, and educational level on marketing efficiency, as it revealed in table 3 . 
Table 3. Estimated Tobit Model

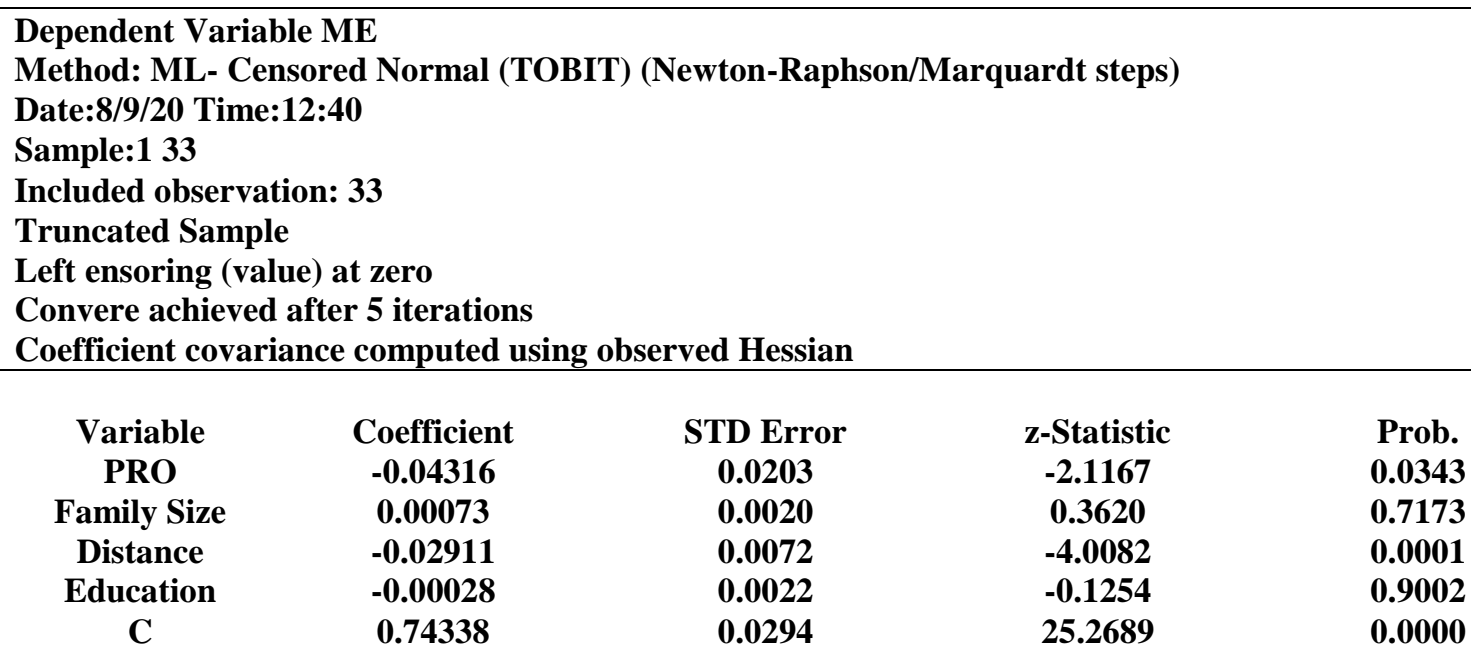

Error distribution

Scale:c(6) $\quad 0.018981$

Mean dependent var: 0.713687

Akaike info. Criterion :-4.7271

Log likelihood : 83.9977
0.002336

S.D.dependent var: 0.023783

Sum squard resid. : 0.01189

Hannan-Quinn criter.:-4.6355
8.124038

0.0000

S.E : 0.020984

Schwarz criteon:-4.7271

Av. Log likelihood:2.545

Right censored obs : 0

Total obs : 33
Left censored obs : 0

Uncensored obs : 33

Source:. According to Eviews program

Results in Table 3 revealed that the productivity variable, which is a quantitative variable, gave a negative sign, which is contrary to economic logic; the increasment in productivity by one ton leads to a decrease in marketing efficiency by $4.3 \%$ and assuming that the rest of the other factors are constant; moreover, the increase in productivity to reduce the average production costs and through equation 1 it will lead to a reduction in the value of marketing efficiency which shows the negative signal of the estimated parameter of mathematical side, but technical side increase the productivity and in accordance with the conditions of research sample of the number labor hours and marketing operations in the farm as gathering, cleaning, drying packing and storage for special conditions, which may affect the marketing efficiency because of the lack of labor and resource it using of those function are marketing, and the family size variable, which is an independent quantitative variable, gave a positive signal, which is in agreement with the economic logic and practical reality of the research sample, and increasing the number of family members by one person leads to an increase in marketing efficiency by $0.07 \%$. The Onion crop required a large family workers to prepare and perform marketing functions within the farm, such as packing, cleaning, sorting and loading for marketing and most of the farms depend on family work. As for the variable of distance from the market, which is an independent quantitative variable, it gave a negative signal, which is in agreement with the economic logic, as increasing the distance by one $\mathrm{Km}$ leads to a reduction in marketing efficiency by $3 \%$ assuming the stability of other factors, since the distance from the market affects the marketing costs and especially the cost of transportation, which is one of the main marketing costs, as it reaches $50 \%$ of the marketing operations cost. While the educational level variable, which is a qualitative independent variable gave a negative value, which is in contrast with the economic logic; generally, the increasment of the educational level by one level leads to a decrease in the amount of marketing efficiency by $0.028 \%$,but the estimated parameter of the independent variable is level of education or academic achievement not statistically significant, that is, it has no effect on marketing efficiency, The estimated model revealed that the productivity variable is the most important and influential in marketing efficiency, followed by the variable of the distance between farm and market, then the 
variables of family size and educational level with less influence; and according to the model, the variables of productivity and distance are significant at the level of $1 \%$ and $5 \%$, and according to the statistic L.R 8.9, which follows the chi square $\chi^{2}$ distribution, and gave a significant value under a degree of freedom 4; accordingly, the overall significance of the model is acceptable as a result of the criteria are fulfilled.

\section{The Estimated Significance Model Test}

In order to test the significance of variables, the Wald statistic test of Tobit model was applied. The test was based on the null hypothesis $\mathrm{H}_{0}$ and the alternative hypothesis $\mathrm{H}_{1}$; since the null hypothesis indicates that the model parameters associated with the explanatory variables are equal to zero, i.e.: $\mathrm{H}_{0}$ $=\mathrm{b} 1=\mathrm{b} 2=\mathrm{b} 3=\mathrm{b} 4=0$, and through table 4 that includes the results of the Wald statistic test, which follows the chi distribution at the degree of freedom d.f 4 and the significance of the parameters of the Tobit regression model as a whole is shown $0.0017<0.05$, this means that the independent variables included in the model have a statistically significant effect to predict the value of the qualitative dependent variable, marketing efficiency according to the data that revealed table 4 consequently, the null hypothesis has been rejected and the alternative hypothesis has accepted.

\begin{tabular}{|c|c|c|c|}
\hline \multicolumn{4}{|l|}{$\begin{array}{l}\text { Wald Test } \\
\text { Equation: EQ01 }\end{array}$} \\
\hline Test Statistic & value & df & Probability \\
\hline F-Statistic & 4.309 & 4.27 & 0.008 \\
\hline Chi-square & 17.23 & 4 & 0.001 \\
\hline \multicolumn{4}{|c|}{$\begin{array}{l}\text { Null Hypothesis: } C(1)=0, C(2)=0, C(3)=0, C(4)=0 \\
\text { Null Hypothesis: }\end{array}$} \\
\hline Nomalized Res. $(=0)$ & & & Std.Err. \\
\hline $\mathbf{C}(\mathbf{1})$ & $-0 .($ & 431 & 0.0203 \\
\hline $\mathbf{C}(2)$ & 0.0 & 07 & 0.0020 \\
\hline $\mathrm{C}(3)$ & -0.0 & 291 & 0.0072 \\
\hline $\mathrm{C}(4)$ & -0.1 & 002 & 0.0022 \\
\hline \multicolumn{4}{|c|}{ Restrictions are Liner in Cofficients } \\
\hline
\end{tabular}

\section{Source :. According to Eviews program}

According to the average value of marketing efficiency, the researchers concluded the possibility to increase the value of marketing efficiency by $29.36 \%$ in the case of efficient use of the resources used in the marketing process, and also the difference in the value of the influence of independent quantitative and qualitative factors on marketing efficiency and according to the parameters values. Moreover, the higher marketing margins in the different marketing channels followed in marketing the crop, as well as the marketing efficiency is low compared to the lack of marketing services provided when marketing the crop, The research recommended the necessity of working to increase the marketing efficiency through government aid to farmers in providing modern means that help in the process of harvesting, cleaning and storage of the crop and paying attention to marketing advice on marketing the crop and providing market information and decrease the high marketing margins received by the intermediary agents, with the necessity to provide a better marketing services. moreover, to raise the farmer's awareness to apply the cooperative marketing method in order to reduce average marketing costs also, the country censorship must be applied to decrease the marketing margins.

\section{REFERENCES}

1. Abbott,J. and J.P,Makehan, 1981 . Agricultural Economics and Marketing in the Tropics. Bangladish, $2^{\text {ed }}$, pp:546

2. Abusaad,H. and M.AL-Saui,2015.An economic study to marketing channel for grape crop in AL-Gharbia province. Egypt university of AL-Mansoura. Journal of Agricultural and Social Sciences. 6(10):1565-1575.

3. AL-Asi,A., 2000. The Marketing Betw-een Theory and Applied . Egypt, university of ALZaqziq, college of trade .2, pp:500.

4. Al-Dabbagh, J. M., 2014. The Agricult-ural Marketing Economics. Iraq. Murtada administration for publication and distribution, pp;728

5. AL-Faraji, A., 2015. The study of economic analysis for the production and market-ing of some vegetable crops in the province of Baghdad agricultural season (summer) Ph.D. dissertation, department of agricultu-ral economics. college of agriculture, unive-rsity of Baghdad. pp:128

6. Ali,E.H., H.J.Muhmed and N.Jassem , 2016. Use probability regression models to study the factors affecting efficiency of the production of Tomato. The AL-Furat Jour-nal of Agricultural Sciences the third scientific conference . pp: 111-117 
7. Ali.E.H., 2016 . Measuring efficiency of the cows by using the quality response models .The Iraqi Journal of Agricultural Science . 47 (2): 600-611

8. Bdewe,N. and G.Thamer. 2017. Efficien-cy of marketing of the table eggs in the private sector in province of Baghdad in 2015. The Iraqi Journal of Agricultural Science . 48 (4): 1021-1031

9. Faeq,M.F and E.H.Ali .2019 . Using probability regression models to measuring management efficiency for broiler projects. The Iraqi Journal of Agricultural Sciences . 50 (Special Issue): 76-83

10. Gujarati, N. D., 2004. Basic Econometrics. Mc-Graw Hil,co.press. $4^{\text {ed }}$ p:580-635

11- http// WWW. FAO. Organization

12. Ismail, M. and M.ALkonibt, 1995. The agricultural marketing. Dar Mars published Riyadh, Saudi Arabia. p:17

13. Jassam, Q., N.Ali and S.Ali , 2018. Economic study to measure the main vegetable crop baghdad province for the agricultural season 2016, Journal of Agricultural and Veterinary Science ,IOSR-JAVS , 11 (7):1115. E-ISSN:2319-2380

14. Jassam, Q.T., 2017. Economic study to measure the efficiency and items of marketing margins of tomato crop year 2015 AL-Taji district, The Iraqi Journal of Agricultural Sciences . 48 (3): 791-796

15. Jassim,H.A., 2015.The Marketing of some fruit crops in the province of Baghdad economics. M.Sc. thesis, department of agricultural economics, college of agriculture university of Baghdad. pp:190

16. Kyomgisha,H., C.Sebta and J.Mugisha, 2018. Potato market access marketing efficiency and on farm value addition in Uganda, Journal Scientific African, 1 (13):14 WWW.Elsevier.com/locate/sciaf

17. Minstery of planning Central Statistical organization. http// www.cosit.gov.Iq.

published reports . 2019
18. Patanaik.D and M.Sharma, 2013 Selection problems for application of probit , tobit , logit and maximum likelihood estimation : A methodological, issue international Journal of Computational Engineering Research , 3 (7):13-29

19. Rit, B.,2014. Studies on marketing efficiency of agricultural products in India a critical evalution . India, International Journal of Multidisciplinary Research and Development . 7:205-210

20. Shehata, E. and S. Mahmud. 2006. Performance efficiency of the human labor input in the animal production sector (A case study). Journal of Contemporary Egypt, 48(2): $525-552$

21. Thamer, G. H., 2013. The efficiency of marketing for the most important vegetable crops in Anbar, Iraq's conservative, field study. Agricultural Research Journal, Kafr AlSheikh university, 39(4): 462-472

22. Thamer,G.H., 2013. The relative importance of the terms of the marketing margin between the wholesale price and consumer price and efficiency of marketing some of the vegetables and fruit crops in the city of Baghdad (Case Study). Agricultural Rese-arch Journal, Kafr Al-Sheikh University, 39(4):449-461

23. Uzzman , R., 2013. Marketing efficiency of board rice in some selected areas of Dinjapur district, Bangladish, Bangala , athesis of master, department of agribusiness and marketing. Bangala agricultural University, pp:94

24. Zaharim.A, A.Shariff and K. uzzaman, 2009. The comparison logit and probit regression analysis in estimating the stren-gth of gear teeth . European Journal of Scientific Research , 27(4): 548-553

25. Zaho, L., C. Yuhan and D. Scheffer, Comparison of logistic regression and linear regression in modeling percentage data, Journal of Applied and Environmental Microbiology , 67(5): 2129-2135. 